\title{
CONSTITUTIONALISATION OF THE PRE-TRIAL CHAMBER CONCEPT
}

DOI: $10.47743 /$ rdc-2019-2-0005

Tudorel TOADER

Professor PhD, Rector

"Alexandru loan Cuza" University of lași

ttoader@uaic.ro

\author{
Marieta SAFTA \\ PhD Associate Professor, \\ "Titu Maiorescu" University of Bucharest, \\ Faculty of Law \\ First assistant magistrate, \\ Constitutional Court of Romania \\ marieta.safta@ccr.ro
}

\section{Abstract}

The Pre-trial Chamber was introduced in criminal proceedings as a new concept aimed at eliminating the excessive length of proceedings in the trial stage, and, at the same time, as a procedural remedy designed to meet the requirements of legality, celerity and fairness of criminal proceedings. The rules governing it have been repeatedly challenged by way of exceptions of unconstitutionality, some of the exceptions being allowed, with the consequent amendment of the legal reference texts. This study approaches the case-law of the Constitutional Court by which the constitutionalisation of this stage of the criminal proceedings was achieved, with the consequence of significant changes, inviting reflection on the new configuration of the Pre-trial Chamber, from the perspective of regulatory intent.

Keywords: Pre-trial Chamber; constitutional review; fair trial; effects of Constitutional Court decisions

\section{Introductory considerations}

The current Criminal Procedure Code has established four stages of the criminal trial, namely: the criminal prosecution stage, the pre-trial Chamber stage, the trial stage and the execution stage. The special part of the Criminal Procedure Code regulates in this respect in Title I on "Criminal Prosecution" in Title II on "Pre-trial Chamber", in Title III on "Trial" and in Title V on "Execution of criminal judgments".

As regards the Pre-trial Chamber Stage, according to the explanatory memorandum to the Draft Law on the Criminal Procedure Code (PL-x no. 412/2009), it was introduced as a "new and innovative concept" that aims to "remove excessive length of proceedings in the trial stage", being, at the same time, a procedural remedy

CONSTITUTIONAL NEWS 
meant "to meet the requirements of legality, celerity and fairness of the criminal proceedings". It is regulated in Articles 342-348 of the Criminal Procedure Code, as follows: Article 342 - The object of the procedure in the Pre-trial Chamber; Article 343 Duration of the procedure in the Pre-trial Chamber; Article 344 - Preliminary measures; Article 345 - Procedure in the Pre-trial Chamber; Article 346 - Solutions; Article 347 The appeal; Article 348 - Preventive measures in the Pre-trial Chamber procedure. The mentioned provisions must be in conjunction with those of Article 54 of the Criminal Procedure Code, which have the general competence of the Pre-trial Chamber Judge, in the sense that he shall verify the legality of the prosecution ordered by the prosecutor, the legality of the administration of evidence and of the performance of procedural acts by the criminal prosecution bodies, settle complaints against non-prosecution or dismissal of charges, settle other situations expressly provided by law, as well as with other provisions of the Code concerning the procedure in the Pre-trial Chamber. There are other provisions applicable because, as it was observed ${ }^{1}$, apart from the specific object of the Pre-trial Chamber stage (regulated by Article 342 of the Criminal Procedure Code), the criminal procedural law establishes other activities on which the Pre-trial Chamber Judge shall be competent to dispose during the Pre-trial Chamber proceedings. Thus, for example, outside the "filter procedure" regulated by Articles 342-348 of the Criminal Procedure Code, it is up to the Pre-trial Chamber Judge to confirm or refute the order to reopen the criminal prosecution (Article 335 para. 4 of the Criminal Procedure Code), the settlement of complaints against solutions of non-prosecution or dismissal of charges (Articles 341-342 of the Criminal Procedure Code), the settlement of complaints in order to take security measures of special confiscation or annulment of a document by the prosecutor of the classification or of the renunciation to the criminal prosecution (Article $549^{1}$ of the Criminal Procedure Code). Within the mentioned "filter procedure", without being specific to this procedure, it should be retained the establishment or maintenance of protection measures specific to the threatened witness (Article 126 para. 7 in relation to Article 127 and Article 128 of the Criminal Procedure Code], taking precautionary measures (Article 249 et seq. of the Criminal Procedure Code), taking, maintaining, replacing, revoking or finding a cessation of law regarding preventive measures against the defendant, as well as verifying the legality and validity of preventive measures ordered prior to the procedure, during the criminal prosecution, the sanctioning with the nullity of the violation of some legal provisions during the Pre-trial Chamber procedure [Article 281 and Article 282 para. 4 letter a) of the Criminal Procedure Code].

The rules governing the concept of the Pre-trial Chamber, as well as those concerning the general competence of the Pre-trial Chamber Judge have been repeatedly challenged by way of exceptions of unconstitutionality, some of the

${ }^{1}$ C. Voicu, D. Atasiei, in N. Volonciu (coord.), The New Code of Criminal Procedure commented, $2^{\text {nd }}$ ed., Hamangiu Publishing House, 2015, p. 920.

CONSTITUTIONAL LAW REVIEW 
exceptions being allowed, with the consequent amendment of the legal reference texts. We will carry out, in the following, a step to synthesize the case-law of the Romanian Constitutional Court in the matter, which made the constitutionalisation of this stage of the criminal trial, with the consequence of significant changes in the concept of the Pre-trial Chamber, changes that naturally raise questions from the perspective of its regulation. Likewise, we will refer, in context, to the decisions of admission adjudicated by the Court which, even if they do not refer to the specific object of the procedural stage of the Pre-trial Chamber, are based on considerations similar to those concerning this object or refer to the general competence of the Pre-trial Chamber judge.

1. The legislative solution that does not allow the participation of the prosecutor, the defendant, the civil party and the civilly liable party in the procedure carried out in the council Chamber, before the Pre-trial Chamber Judge, in settling the appeal in the Pre-trial Chamber procedure, as well as the complaint by the Pre-trial Chamber Judge.

In the merits of the Pre-trial Chamber, as well as in the judicial review stage, the legislator must grant the civil party and the civilly liable party the same rights as the defendant, given the object of the Pre-trial Chamber proceedings, the outcome of this procedural stage, its influence on the merits of the trial and the right of these parties, to propose the administration of evidence by the judicial bodies, to raise exceptions and to draw conclusions, to formulate any other requests related to the settlement of the criminal side of the case and to access the file.

The decisions by which the Romanian Constitutional Court ruled in the sense shown above ${ }^{2}$ produced substantive changes to the procedural stage of the Pre-trial Chamber, in the sense of introducing the oral procedure, based on adversarial proceedings and, respectively, extending the scope of the participants.

Thus, in the initial wording of Articles 344, 345, 346 para. 1 and Article 347 of the Criminal Procedure Code, this stage was not carried out according to an oral procedure, but on the basis of those submitted in writing by the defendant and the response of the Prosecutor's Office and excluding other parties that could also justify a legitimate interest. By Romanian Constitutional Court's Decision no. 641 of November $11^{\text {th }}, 2014^{3}$, the Court found that are unconstitutional the legislative solutions contained in Article 345 para. 1 and in Article 346 para. 1 of the Criminal Procedure Code, according to which the Pre-trial Chamber Judge rules "without the

2 Must see the Romanian Constitutional Court's Decision no. 599 of October 21 ${ }^{\text {st }}, 2014$, published in the Official Gazette of Romania no. 886 of December $5^{\text {th }}, 2014$, Decision no. 641 of November $11^{\text {th }}, 2014$, published in the Official Gazette of Romania no. 887 of December $5^{\text {th }}, 2014$, Decision no. 663 of November $11^{\text {th }}, 2014$, published in the Official Gazette of Romania no. 52 of January 22 ${ }^{\text {nd }}, 2015$.

${ }^{3}$ Published in the Official Gazette of Romania no. 887 of December $5^{\text {th }}, 2014$. 
participation of the prosecutor and the defendant", the provisions of Article 344 para. 4 regarding the procedure without contradiction/pleadings in this procedural stage, as well as those of Article 347 para. 3 of the Criminal Procedure Code, related to those of Article 344 para. 4, Article 345 para. 1 and Article 346 para. 1 of the Criminal Procedure Code regarding the application of the same rules within the appeal procedure in the pre-trial Chamber.

In terms of the scope of the participants, the Court noted that, according to Article 32 of the Criminal Procedure Code, besides the defendant, the civil party and the civilly liable party are parties to the criminal proceedings. Regarding the civil party, the Romanian Constitutional Court, by Decision no. 482 of November $9^{\text {th }}, 2004^{4}$, ruled that if the injured party makes claims in the criminal proceedings for compensation for material damage suffered as a result of the crime, she has two procedural qualities: the quality of the injured party and the quality of civil party. However, these two parts of the criminal trial are in an identical situation, namely in the situation of a person injured in his rights by committing the crime, which justifies the existence of the "legitimate interest", referred to in Article 21 of the Romanian Constitution. Also, regarding the civilly liable party, the Court found that, according to Article 86 of the Criminal Procedure Code, this is the person who, in accordance with the civil law, has a legal or conventional obligation to repair in whole or in part, alone or jointly, the damage caused by the offence and who is called to answer in the proceedings. Although it does not identify itself, from the regulation of the obligations incumbent upon the civilly liable party, it appears that the latter together with the defendant form a procedural group that has to repair the damage caused by the offence. Thus, the civilly liable party has an interest in removing the conditions that would attract his/her civil liability. Moreover, according to Article 85 para. 1 and Article 87 para. 1 of the Criminal Procedure Code, both the civil party and the civilly liable party enjoy the rights provided in Article 81 of the Criminal Procedure Code, of which the Court retains their right to propose the adduce of evidence by judicial bodies, to raise exceptions and to draw conclusions, to formulate any other requests related to the settlement of the criminal side of the case and to access the file, in accordance with the law. From this perspective, the Court considered that the civil and civilly liable party has no interest in settling the criminal side of the case, given that the determination of the existence of the criminal act and the guilt of the defendant in question also depends on settling the civil side of the case.

With regard to the right to an oral procedure and a public hearing, the Court noted that it is particularly important in the criminal context, in which case a person accused of an offence should generally have the opportunity to attend a hearing at first

${ }^{4}$ Published in the Official Gazette of Romania no. 1200 of December $15^{\text {th }}, 2004$.

\section{CONSTITUTIONAL LAW REVIEW}


instance ${ }^{5}$. If there is only one degree of jurisdiction and the issues are not "extremely technical" or "purely legal", there must be an oral procedure, the written procedures being insufficient ${ }^{6}$. Only in oral debates the trial can be effectively followed, in the sequence of its stages, by the parties. At the same time, the right to an oral procedure also contains the right of the defendant, the civil party and the civilly liable party to be present before the court. This principle ensures direct contact between the judge and the parties, ensuring that the statement of objections made by the parties follows a certain order and thus facilitates the correct determination of the facts (para. 57).

The Court held that the outcome of the procedure in the pre-trial Chamber concerning the determination of the legality of the evidence and proceedings by the prosecution had a direct influence on the conduct of proceedings on the substance and could be decisive for establishing the guilt or innocence of the defendant. However, by regulating the pre-trial Chamber procedure and taking into account the influence that this procedure has on subsequent stages of the trial, the Court found that the legislator violated the right of the parties to a fair trial in its component on adversarial proceedings, pleadings and equality of arms. According to the Court, in view of the requirements of the right to a fair trial, it is sufficient to provide the parties with the opportunity to participate in this procedural stage, the judge being able to decide on the completion of the procedure in the pre-trial Chamber without the participation of the parties as long as they have been legally summoned.

Noting that, according to Article 347 para. 3 of the Criminal Procedure Code, the provisions of Article 343-346 of the Criminal Procedure Code apply accordingly and with regard to the appeal regarding the solution pronounced by the pre-trial Chamber judge, the Court noted that the foregoing also applies mutatis mutandis to the appeal procedure against the solution pronounced by the pre-trial Chamber judge.

Even if it does not refer to the provisions contained in Title II - Pre-Trial Chamber, namely to the specific object of the pre-trial Chamber procedure, we will mention here the decisions pronounced by the Romanian Constitutional Court, regarding the provisions of Article 341 of the Criminal Procedure Code - Settlement of the complaint by the pre-trial Chamber judge, in order to emphasize the unit of legal reasoning. Thus, in view of the similar regulation, by the provisions of Article 341 of the Criminal Procedure Code, on the settlement of the complaint against the solutions of non-prosecution or dismissal of charges ordered by the pre-trial Chamber judge, for considerations similar to the above, by Romanian Constitutional Court's Decision no. 599 of October $21^{\text {th }}, 2014$, the Court found that the legislative solution contained in Article 341 para. 5 of the Criminal Procedure Code, according to which the pre-trial Chamber judge decides on the complaint "without the participation of the complainant, the prosecutor and the defendants" is unconstitutional. Thus, the Court noted that for

${ }^{5}$ ECtHr, judgment of July 20th 2000 , in the case Tierce and Others v. San Marino, para. 94.

${ }^{6}$ ECtHr, judgment of December 10 ${ }^{\text {th }}, 2009$ in the case Koottummel v. Austria, para. 18-21 (para. 54).

CONSTITUTIONAL NEWS 
aggrieved parties, civil parties or even civilly liable parties who have suffered from facts allegedly criminal to have full enjoyments of their rights, it is necessary that they use not only a purely written procedure, but also an adversarial procedure and pleadings, essential components of the right to a fair trial. So, in view of the adversarial procedure and oral arguments as essential elements of equality of arms and the right to a fair trial, the Court found that the law shall provide the possibility of the parties, of the main procedural subjects and the prosecutor to actually discuss the observations to the pre-trial Chamber judge. Therefore, in order to achieve these guarantees, they need to be summoned.

Also, by Romanian Constitutional Court's Decision no. 663 of November $11^{\text {th }}, 2014$, the Court found that the legislative solution contained in Article 341 para. 10 of the Criminal Procedure Code according to which the pre-trial Chamber judge rules "without the participation of the prosecutor and the defendant" is unconstitutional. The Court held in this regard that in cases in which criminal proceedings have been instituted, the pre-trial Chamber judge, after removing the non-existence of aspects related to the lateness or inadmissibility of the complaint against the solution of non-prosecution or dismissal of charges, also verifies the legality of administration of evidence and prosecution. If the pre-trial Chamber judge allows the complaint and orders the commencement of the judgment which has the validity of an indictment, therefore, a criminal charge, the prosecutor and the defendant may appeal against those verifications, meaning that the appeal shall be settled "without the participation of the prosecutor and the defendant". Being final from the perspective of formulating the accusation in criminal matters, it is obvious that the issues recorded in the conclusion given on establishing the legality of the administration of evidence and the procedural acts undertaken by the prosecution bodies have a direct influence on the course of the proceedings on the substance and can be decisive for determining, in this case, the guilt or innocence of the accused. The Court considered that this legislative solution is similar to the one contained in Article 341 para. 5 of the Criminal Procedure Code and identical to the one contained in Article 347 para. 3 in relation to Article 345 para. 1 and Article 346 para. 1 of the Criminal Procedure Code, regarding which, by Romanian Constitutional Court's Decisions no. 599 of October 21 $1^{\text {st }}, 2014$ and no. 641 of November $11^{\text {th }}, 2014$, it ruled that the trial of the complaint or appeal without the participation of the parties, the main subjects and the prosecutor contravenes the right to a fair trial in its adversarial and oral components, as the legal rule does not allow the communication to all parties of documents that are likely to influence the decision of the judge and does not provide to all parties with the possibility to effectively discuss the observations submitted to Court. From the perspective of the right to a fair trial, it is sufficient to ensure the parties with the possibility to participate in the debates, the judge being able to decide on the completion of the pre-trial Chamber procedure and without their participation as long as they have been legally summoned. Also, as long as the evidence represents the quintessence of any criminal trial and the prosecution body

CONSTITUTIONAL LAW REVIEW 
gathers and manages evidence both in favour and against the defendant, then it is obvious that the procedure carried out in these situations has a direct influence on the subsequent conduct and fairness of the procedure, including the trial itself, all the more so since, according to Article 341 para. 11 of the Criminal Procedure Code, "evidence that has been excluded cannot be taken into account in the trial on the merits of the case" being necessary the participation of the prosecutor. At the same time, the Court found that, during criminal proceedings, unlike the parties, the prosecutor fulfils a constitutional role enshrined in Article 131 para. 1 of the Romanian Constitution, according to which, "within the judicial activity, the Public Ministry shall represent the general interests of the society and defend legal order, as well as the citizens' rights and freedoms". This fact should not be understood as a subjective right of the prosecutor, because he, by virtue of the role shown above, is a competent authority to investigate and settle the case, exercising his powers in light of the constitutional requirements set out above. Unlike Article $278^{1}$ para. 5 of the Criminal Procedure Code of 1968, according to which the presence of the prosecutor was mandatory, in this regulation enshrined in the impugned legal provisions, the non-compulsory participation of the prosecutor would place the role of the Public Ministry in an area lower than the constitutional provision. Therefore, as long as the pre-trial Chamber procedure may lead to the commencement of the trial and to the prosecution of a criminal charge with obvious consequences for the citizens' rights and freedoms, the Court has found that, in order to achieve these public policy objectives, only the summoning of the prosecutor is insufficient, meaning that his mandatory participation in the procedure is also required. In conclusion, the same reasons also apply to the adjudication of the appeal as to the manner in which the exceptions concerning the lawfulness of managing the evidence and conducting the prosecution were settled, which is why the Court is to find that the legislative solution according to which the pre-trial Chamber judge adjudicates "without the participation of the prosecutor and the defendant" is unconstitutional, as it interferes with the right to a fair trial.

\section{Restricting the scope of the appellants in the pre-trial Chamber only to the prosecutor and defendant is unconstitutional.}

In a natural continuation of the solutions shown above and the considerations that substantiated them, by Romanian Constitutional Court's Decision no. 631 of October $\mathbf{8}^{\text {th }}, \mathbf{2 0 1 5 ^ { 7 }}$, the Court ruled that the legislative solution contained in Article 347 para. 1 of the Criminal Procedure Code is unconstitutional, according to which only the "prosecutor and the defendant" can appeal regarding the manner in which requests and exceptions were settled, as well as against solutions contained in Article 346 para. 3-5 of the Criminal Procedure Code.

${ }^{7}$ Published in the Official Gazette of Romania no. 831 of November $6^{\text {th }}, 2015$.

CONSTITUTIONAL NEWS 
Invoking Decision no. 641/2014, cited above, the Court ruled that access, formulation and exercise of appeal in the pre-trial Chamber is an aspect of free access to justice, a fundamental right protected by Article 21 of the Romanian Constitution. Under these circumstances, the restriction of the scope of the appellants in the pre-trial Chamber only to the prosecutor and the defendant determines the violation of the right of access to justice - enshrined in Article 21 of the Basic Law and Article 6 of the ECHR of the civil party and the civilly liable party, having regard to the fact that, as the Court has held, the outcome of the pre-trial Chamber procedure on the legality of evidence gathered and the procedural acts undertaken by the prosecution has a direct influence on the course of the proceedings on the substance and can be decisive for determining the guilt or innocence of the accused. The civil party, as well as the civilly liable party must have the possibility, like the accused and the prosecutor, to challenge the decisions of the pre-trial Chamber judge by the decision pronounced under the conditions of Article 346 para. 1 of the Criminal Procedure Code regarding the manner in which the requests and the exceptions were settled, as well as against the solutions for returning the case to the prosecutor's office - in case of irregularities of the notification act, the total exclusion of gathered evidence during prosecution, the failure to remedy, in time, by the prosecutor's office the irregularities of the notification act or regarding the cases in which the judge excluded one or more administered evidence or found the nullity of the criminal prosecution acts undertaken in violation of the law, provided that the excluded evidence may not be considered on the course of the proceedings on the substance. At the same time, considering, on the one hand, the influence that the pre-trial Chamber procedure has on the subsequent trial stages, and, on the other hand, the fact that the solutions contained in Article 346 para. 3-5 of the Criminal Procedure Code covers all parties to the proceedings, the Court held that the injured person, being a special passive subject in the case of committing many acts under criminal law, as a subject of the conflict of criminal law which is the subject of criminal proceedings, must be give the possibility to file an appeal in the pre-trial Chamber against the decision contained in Article 346 para. 1 of the Criminal Procedure Code, both regarding the manner in which requests and exceptions are settled, as well as against the solutions contained in Article 346 para. 3-5 of the Criminal Procedure Code. This is due to the fact that, since the procedural position of the injured person is an active procedural, subject in the criminal side, having the right to undertake, in the stage of the pre-trial Chamber, as well as the civil party and the civilly liable party, procedural acts according to Article 81 of the Criminal Procedure Code - respectively the right to propose the administration of evidence by the judicial bodies, to raise exceptions and to draw conclusions, to formulate any other requests related to the settlement of the criminal side of the case and to access the file. Consequently, the provisions of Article 347 para. 1 of the Criminal Procedure Code are unconstitutional, being contrary to the constitutional provisions regarding the free access to justice, as long as they do not give the injured person, the civil party and the civilly liable party the 
right to file an appeal regarding the manner in which the requests and exceptions are settled, as well as against the solutions contained in Article 346 para. 3-5 of the Criminal Procedure Code.

3. It is unconstitutional to regulate the possibility of the injured person, who has become a civil party, to require the civilly liable party to become a party in the criminal proceedings "until the commencement of the criminal investigation", in any procedural stage, including after closing the pre-trial Chamber procedure.

As grounds for the exception of unconstitutionality, the author invoked the Decision of the Constitutional Court no. 641 of November $11^{\text {th }}, 2014^{8}$, para. $35-37$, to emphasize the importance of the pre-trial Chamber and underlined that, in the circumstances where the injured party becomes a civil party in the criminal proceedings during the trial, after the pre-trial Chamber stage has been undertaken, the party, by an abuse of procedural law, deprives the civilly liable party of the right to make claims and exceptions regarding the jurisdiction and legality of the court of law, the legality of evidence gathered and the procedural acts undertaken by the prosecution, the only remaining means of defence regarding the validity of the evidence gathered throughout the criminal trial and the administration of evidence other than those gathered throughout the criminal trial. Given that the civilly liable party forms together with the accused a procedural group obliged to repair the damage caused by the crime, he cannot be conditioned, respectively he cannot be forbidden to exercise, effectively, the procedural rights recognized by law, depending on the simple manifestation of another procedural party's will.

Having examined the exception of unconstitutionality, the Court held, in essence, by Romanian Constitutional Court's Decision no. 257 of April $26^{\text {th }}, 2017^{9}$ that, de lege lata, the constitution of a civil party can take place "until the commencement of the criminal investigation". Neither the prosecutor nor the court of law can limit the availability of the civil action, as none of these judicial bodies can subrogate to the rights of the injured person. However, according to Article 20 para. 1, second thesis of the Criminal Procedure Code, the aforementioned judicial bodies have the obligation to inform the injured person that she may become a civil party in the criminal proceedings, under the conditions of Article 111 of the Criminal Procedure Code - at the beginning of the first hearing, when the injured person shall be informed of her rights and obligations, of Article 353 of the Criminal Procedure Code - by summoning the injured person for the first trial, stating that she may become a civil party until the commencement of the criminal investigation and of Article 374 para. 3 of the Criminal Procedure Code - which provides that, at the first term at which the summons procedure is legally fulfilled and

\footnotetext{
${ }^{8}$ Published in the Official Gazette of Romania no. 887 of December $5^{\text {th }}, 2014$.

${ }_{9}^{9}$ Published in the Official Gazette of Romania no. 472 of June 22nd 2017.
} 
the case is ongoing, the president shall inform the injured person that she may become a civil party until the commencement of the criminal investigation. The Court notes that this obligation still has a justification in terms of the active role that the judiciary must play, even though the current criminal procedure law, not regulating this principle, has given the judge a more passive role, similar to that of adversarial systems, the prosecutor still maintaining an active role in the criminal proceedings.

Furthermore, the Court held that the formulation of the application for becoming a civil party triggers the civil action, at the same time giving rise to the (defence) counteraction of the person or persons against whom the civil action is directed, the passive subject of the civil action may be the accused or the civilly liable party. The "introduction" in the criminal trial of the civilly liable party may take place, under the conditions of Article 21 of the Criminal Procedure Code "upon request of the party entitled under civil law", within the term provided for in Article 20 para. 1 of the Criminal Procedure Code, therefore "until the commencement of the criminal investigation". Likewise, according to the criminal procedural law in force, when exercising the civil action, the prosecutor is obliged to request the introduction in the criminal proceedings the civilly liable party, under the conditions of Article 21 para. 1 of the Criminal Procedure Code, in compliance with the aforementioned term.

Furthermore, the civilly liable "person", exposed to a separate civil proceeding, has the interest to "intervene", as a civilly liable party, in the criminal trial in which the civil proceedings is being tried and a judgment will be issued, according to Article 28 para. 1 of the Criminal Procedure Code, which shall have the authority of res judicata before the civil court of law, regarding the existence of the offence and of the person who committed it, so that pursuant to Article 21 para. 3 of the Criminal Procedure Code, the civilly liable party may interfere within the criminal proceedings until the cessation of the criminal investigation at the first instance court of law, taking the procedure from the stage in which it is at the time of the intervention.

By becoming a party in the criminal proceedings or by intervening in the proceedings, the civilly liable "person" becomes a "party" in the civil action within the criminal proceedings and, in this capacity, she implicitly acquires the procedural rights inherent to the accused's counteraction regarding the civil action within the criminal proceedings, so she can invoke any existing evidence in the criminal file or can propose the administration of new evidence that would prove that the claims of the civil party are unfounded. However, in addition to the conditions imposed on the "person" civilly liable in order to be able to interfere with the criminal proceedings and to acquire, in this way, the capacity of "party" in the trial - and which are procedural capacity to exercise and use, standing, the assertion of an interest before the judiciary, the connection between the main application and that of the participation of the civilly liable party in the judicial activity - likewise, there must be a pending civil trial, so the civil action must have been initiated within the criminal proceedings, and it depends, as indicated above, on the manifestation of the injured person's will, which can be 


\section{Constitutionalisation of the Pre-trial Chamber concept}

expressed at any stage of the criminal proceedings, "until the commencement of the criminal investigation" in question.

The Court recalled that by Romanian Constitutional Court's Decision no. 641 of November $11^{\text {th }}, 2014$ and no. 631 of October $8^{\text {th }}, 2015$, the Court ruled that the pre-trial Chamber judge shall be sovereign over establishing the legality of the evidence gathered and the procedural acts undertaken by the prosecution, being the only one who can assess these elements and the acts he performs have a direct influence on the conduct and fairness of the trial. Once the trial has begun, the judge on the substance can no longer assess the evidence excluded in the pre-trial Chamber, but also the legality of the evidence gathered that remained available in the trial. Furthermore, by the same decisions, the Court ruled on the mandatory participation, with full rights, of the civil party and the civilly liable party in the proceedings held in the council Chamber, before the pre-trial Chamber judge, both on the merits and in the judicial review stage of the appeal.

Based on these premises and taking into account the criticisms formulated by the author of the exception of unconstitutionality in question - according to which the civilly liable party "introduced" in the trial after the completion of the pre-trial Chamber is unable to formulate requests and exceptions on the competence and legality of the referral brought before the court of law, the legality of the evidence gathered and the procedural acts undertaken by prosecution - the Court held that, after the decision pronounced by the pre-trial Chamber judge remained final, there is no legal basis on which the civilly liable party, which was not present in the pre-trial Chamber, can be able to formulate requests or exceptions regarding issues already analysed in this procedural stage, in particular regarding the legality of the evidence used to establish the existence, respectively the extent of the damage (expert reports or statement of findings). However, as the Court has ruled, the outcome of the pre-trial Chamber procedure on establishing the legality of the evidence gathered and the procedural acts undertaken by the prosecution has a direct influence on the course of the proceedings on the substance and can be decisive for determining the guilt or innocence of the accused, an aspect upon which the settlement of the civil part of the criminal proceedings essentially depends.

The Court found that, as the introduction of the injured person as a civil party can be done in any procedural stage "until the commencement of the criminal investigation" - the introduction in the criminal proceedings of the civilly liable party, as well as the possibility of the civilly liable party to interfere with the criminal proceedings, being correlated with the introduction of a civil party in criminal proceedings - the effective exercise by the civilly liable party of procedural rights - recognized by law and established in the case-law of the Constitutional Court - in the pre-trial Chamber stage, therefore, the free access of such party depends exclusively on the manifestation of will of the injured person. However, the Court states that the injured person, who has become a civil party in the criminal proceedings, has interests contrary to the civilly liable party, so there is a possibility that he may exercise his right to seek redress

CONSTITUTIONAL NEWS 
through the courts abusively, in order to limit/exclude the access of the civilly liable party in the preliminary Chamber stage which, as shown above, has a special importance on the subsequent trial stages in terms of its object. Thus, the possibility of the injured person, who has become a civil party, to request the introduction in the criminal proceedings of the civilly liable party "until the commencement of the criminal investigation", in any procedural stage, including after the closure of the pre-trial Chamber procedure, is likely to bring infringement to the right of free access to justice of the civilly liable party, enshrined in Article 21 of the Basic Law.

In other words, the protection granted to the injured party's right of access to justice who has become a civil party and who may request the civilly liable party to be introduced in the criminal proceedings "until the commencement of the criminal investigation" determines the limitation of the civil party's right of free access to justice. Under those circumstances, it is necessary for the legislator to use appropriate means to ensure that that limitation is proportionate to the aim pursued, since the absolutization of one of the two rights - provided that their scope is concurrent - could cause damage to the substance of the other right. Likewise, the criminal procedural norms of Article 21 para. 1 of the Criminal Procedure Code, regulating the possibility of the injured person who has become a civil party to request the introduction in the criminal proceedings of the civilly liable party "until the commencement of the criminal investigation", are not able to maintain the balance between the fundamental rights in competition. In this respect, the Court retained para. 15 of the Romanian Constitutional Court's Decision no. 741 of December $13^{\text {th }}, 2016^{10}$, considering that those previously found by the Court are applicable mutatis mutandis also in the hypothesis in which the prosecutor exercises the civil action, under the conditions of Article 20 para. 1 and 2 of the Criminal Procedure Code, and is obliged, according to Article 21 para. 2 of the Criminal Procedure Code, to request the introduction in the criminal proceedings of the civilly liable party, under the conditions Article 21 para. 1 of the Criminal Procedure Code. Thus, the Court allowed the exception of unconstitutionality and found that the phrase "within the term provided for in Article 20 para. 1" contained in Article 21 para. 1 of the Criminal Procedure Code is unconstitutional.

4. It is unconstitutional to regulate the impossibility of the pre-trial Chamber judge to adduce any evidence besides "any new documents submitted". In the pre-trial Chamber procedure, the verification of the legality of the adduction of evidence by the prosecution is necessary to be carried out directly in adversial proceedings with the parties and the injured party, with the possibility of bringing any evidence.

By Romanian Constitutional Court's Decision no. 802 of December $\mathbf{5}^{\text {th }}, \mathbf{2 0 1 7 ^ { 1 1 }}$, the Court ruled that the criminal procedural rules of Article 345 para. 1 of the Criminal

${ }^{10}$ Published in the Official Gazette of Romania no. 127 of February $17^{\text {th }}, 2017$.

${ }^{11}$ Published in the Official Gazette of Romania no. 116 of February 6 ${ }^{\text {th }}, 2018$. 
Procedure Code, as amended by Law no. 75/2016, which do not allow the pre-trial Chamber judge - in the settlement of the claims and exceptions formulated and the exceptions raised ex officio - to adduce any evidence, apart from "any new documents submitted", are in contradiction with the constitutional provisions regarding the independence of the judge in carrying out the act of justice. As noted by the Romanian Constitutional Court in Decision no. 54 of January $14^{\text {th }}, 2009^{12}$, "in the field of law enforcement in a case brought before the court, including the legality of the adduction of evidence, the expert is the judge of the case himself, who, by virtue of his professional training and his statute of independence, has the power to decide on the legal relationships brought before the court, the evidence gathered and the applicable legal rules". The independence of the judiciary allows judges to fulfil their role of protectors of citizens' rights and freedoms ${ }^{13}$, the criminal procedure rule contained in Article 345 para. 1, as amended by Law no. 75/2016, not ensuring full jurisdiction over issues that are the subject of the pre-trial Chamber - specifically, regarding the verification of the legality of the adduction of evidence - so that the charge in criminal matters is not subject to the full review of an independent and impartial magistrate. Therefore, the Court found that, due to a formalism that is harmful to the establishment of truth and justice as the ultimate value referred to in Article 1 of the Basic Law, the legislator regulated, by Article 345 para. 1 of the Criminal Procedure Code, as was amended by Law no. 75/2016, an unconstitutional text.

To the same extent, the Court found that the provisions of Article 345 para. 1 of the Criminal Procedure Code, as amended by Law no. 75/2016, unjustifiably restrict the right of the parties and injured parties to defend within this procedure. The right to defence, regulated in Article 24 of the Romanian Constitution, gives any party involved in a trial, according to his own interests and regardless of the nature of the trial, the opportunity to use all means provided by law to invoke in its defence facts or circumstances. This right means participation in court hearings, the use of evidence, the invocation of exceptions provided by the criminal procedural law, the exercise of any other criminal procedural rights and the possibility to benefit from the services of a lawyer.

At the same time, the provisions of Article 345 para. 1 of the Criminal Procedure Code, as amended by Law no. 75/2016, also infringe the constitutional provisions of Article 21 para. 3 on the right to a fair trial, in its component regarding the equality of arms, as well as those of Article 6 of the ECHR, in the light of Article 20 of the Constitution. As noted by the Romanian Constitutional Court in Decision no. 641 of November $11^{\text {th }}, 2014$, cited above, para. 38 , a fundamental aspect of the right to a fair trial is that, in criminal matters, including procedural elements should take place within a contradictory manner, there must be equality of arms between the prosecution and

12 Published in the Official Gazette of Romania no. 42 of January $23^{\text {rd }}, 2009$.

${ }^{13}$ In this sense, Romanian Constitutional Court's Decision no. 629 of November $4^{\text {th }}, 2014$, published in the Official Gazette of Romania no. 932 of December 21st, 2014.

CONSTITUTIONAL NEWS 
the defence. The right to an adversarial trial means, in a criminal proceedings, that both the prosecutor and the accused must be given the opportunity to have knowledge and to be able to make observations upon all the evidence submitted or upon the observations submitted by the other party in order to influence the decision of the court of law ${ }^{14}$. National law may satisfy this requirement in various ways, but the method adopted by it must ensure that the opposing party is aware of the submission of the observations and has a genuine opportunity to comment on them ${ }^{15}$. However, having examined the provisions of Article 345 para. 1 of the Criminal Procedure Code, as amended by Law no. $75 / 2016$, which establish that the pre-trial Chamber judge shall settle the claims and exceptions made by the parties and the injured party only on the basis of the proceedings and the material in the criminal investigation file and of "any new documents submitted", the Court found that the parties and the injured party are objectively unable to effectively challenge the legality of the evidence, when for proving the non-legality of the evidence gathered in the criminal investigation they are required to bring evidence other than the new documents submitted by them. In other words, the right to defence and equality of arms are defeated, as long as, for the settlement of the claims and exceptions made, in order to prove the illegal nature of the evidence gathered in the criminal investigation stage, the parties and the injured party may request, and the pre-trial Chamber judge may approve, only the adduction of the evidence with "the new documents submitted".

Referring to the case-law of the European Court of Human Rights in this matter, the Romanian Constitutional Court held that the European Court of Justice has ruled on the need to carefully examine the judicial proceedings by which evidence is gathered in criminal proceedings, the real, adequate and sufficient possibility to challenge the legality of evidence gathered in the "investigation" stage (criminal investigation), aspects that presuppose, in concrete, the possibility for the parties to use all the means provided by law to invoke facts or circumstances in their defence, including the adduction of any evidence that would prove the non-legality of the evidence gathered by prosecution. As a result, the Court found that, in regulating the impugned criminal procedural rules, it is necessary to take over the conventional standard previously exposed, given that Article 345 para. 1 of the Criminal Procedure Code, as amended by Law no. 75/2016, regulates the possibility of the parties and the injured party to challenge the adduction of evidence during prosecution stage, but does not provide the tools, the procedural means to prove that they are not legal. Having examined the current content of the provisions of Article 345 para. 1 of the Criminal Procedure Code, the Court has noted that the legitimacy of the judgment based on evidence unlawful taken during the prosecution stage and unchallenged effectively by the parties and the injured party in the pre-trial Chamber procedure will be undetermined. Therefore, the

${ }^{14}$ ECtHR, judgment of February $16^{\text {th }}, 2000$, in case Rowe and Davis v. the United Kingdom, para. 60.

15 ECtHR, judgment of August 28 $8^{\text {th }}, 1991$, in case Brandstetter v. Austria.

CONSTITUTIONAL LAW REVIEW 
Court held that - accepting the possibility that evidence unlawful taken during the prosecution stage and unchallenged effectively in the pre-trial Chamber procedure could form the basis of a conviction - the conventional standard set out above would be circumvented, such a legislative solution not being possible proportionate to the objective proposed in the Explanatory Memorandum to the Draft Law on the Criminal Procedure Code, namely "removing the excessive length of proceedings during the trial stage" and "ensuring the premises for the settlement of the case on the merits as soon as possible".

5. The legislative solution contained in the provisions of Article 347 para. 1 of the Criminal Procedure Code is unconstitutional, in the form in force prior to the amendment by Law no. 75/2016, which excludes the appeal against the decision by which the pre-trial Chamber judge ordered the commencement of the trial-as he found that no claims and exceptions were made and did not raise exceptions ex officio - as it creates discriminatory treatment for the accused, the injured party, the civil party and the civilly liable party in that case in relation to the parties and the injured parties who, in turn, remained liable in those criminal cases in which the pre-trial Chamber judge raised, ex officio, exceptions or claims and exceptions were made by a participant in the trial other than the appellant - on the one hand, the party, the injured party or the prosecutor - and, on the other hand, the prosecutor lacks the necessary tools to exercise his specific role in the criminal proceedings.

Accordingly, the legislative solution contained in Article 341 para. 9 of the Criminal Procedure Code is unconstitutional, which excludes the possibility to challenge the judgment of the pre-trial Chamber judge regarding the order to start the trial about the facts and parties for which, during prosecution, the criminal action was initiated, pronounced on the basis of Article 341 para. 7 pnt. 2 letter c) of the Criminal Procedure Code.

In this regard, by Romanian Constitutional Court's Decision no. 18 of January $17^{\text {th }}$, $\mathbf{2 0 1 7 ^ { 1 6 }}$, the Court noted that the provisions of Article 347 para. 1 of the Criminal Procedure Code, in the wording prior to the amendment by Law no. 75/2016 ${ }^{17}$, provide the possibility of challenging, by way of appeal, separately or cumulatively, two distinct levels of the solutions pronounced in the pre-trial Chamber procedure. A first level is the way in which claims and exceptions are settled, in which case the appellant brings criticisms to the manner in which claims and exceptions were, as the case may be,

\footnotetext{
16 Published in the Official Gazette of Romania no. 312 of May 2nd 2017.

${ }^{17}$ Regarding the approval of the Government Emergency Ordinance no. 82/2014 for amending and supplementing Law no. 135/2010 on the Criminal Procedure Code, published in the Official Gazette of Romania no. 334 of April $29^{\text {th }}, 2016$.
} 
allowed or dismissed by the pre-trial Chamber judge by the interim judgment pronounced pursuant to Article 345 para. 1 of the Criminal Procedure Code - provided that for this interim judgment there is no separate appeal, as it may be a subject to analysis only with the appeal of the final judgment - or by the final judgment provided for by Article 346 para. 3 and 4 of the Criminal Procedure Code. The manner of reforming this solution may influence the settlement of the pre-trial Chamber stage of the criminal proceedings, in the sense of retaining a solution other than the one of the pre-trial Chamber judge from the court of first instance. The second level refers to the modalities for the settlement of the pre-trial Chamber procedure based on Article 346 para. 3 and 4 of the Criminal Procedure Code. In this case, the appellant brings criticisms either to the solution of giving the case to the prosecutor's office based on Article 346 para. 3 of the Criminal Procedure Code, or to the solution of ordering the commencement of the trial under Article 346 para. 4 of the Criminal Procedure Code when the pre-trial Chamber judge noted irregularities in the indictment, but found that they were not harmful to the possibility of establishing the object and limits of the trial, or ruled out one or more pieces of evidence or invalidated certain criminal proceedings, without the appellant necessarily bring criticisms also to the manner in which claims and exceptions were settled. The Court noted that, erroneously, Article 347 para. 1 of the Criminal Procedure Code, in the wording prior to the amendment by Law no. $75 / 2016$, refers, in view of solutions, to Article 346 para. 5 , given that the latter text of law does not contain any provision regarding any solution, but provides that "the excluded evidence cannot be taken into account in the trial on the merits of the case".

The Court found that the exclusion of the possibility to file an appeal against the judgment of the pre-trial Chamber judge pursuant to Article 346 para. 2 of the Criminal Procedure Code, in the wording prior to the amendment by Law no. $75 / 2016$, is likely to infringe the equality of rights between citizens as regards the recognition of the fundamental right of free access to justice. Thus, the Court held that, by way of the appeal provided by Article 347 of the Criminal Procedure Code, a legality review is ensured regarding a series of final judgments pronounced in the pre-trial Chamber procedure, as a guarantee of compliance with the requirements of the principle of legality of criminal proceedings enshrined in Article 2 of the Criminal Procedure Code, which in turn has its basis in the provisions of Article 1 para. 5 of the Romanian Constitution regarding the principle of legality. The purpose of the appeal in the pre-trial Chamber procedure is to correct the errors of law committed by the pre-trial Chamber judge in verifying, after the trial, the legality of the referral brought before the court of law, as well as the legality of the adduction of evidence and the procedural acts undertaken by prosecution, errors to be remedied in the same procedural stage, having regard to the reasons why the pre-trial Chamber procedure was instituted. However, such errors of law may also occur in those situations in which no claims and exceptions have been made in the pre-trial Chamber procedure and no exceptions have been raised ex officio. Under these circumstances, the Court found that the passivity of the parties and the injured party cannot be an objective criterion for excluding them from 
the exercise of the right to appeal, given that this right is recognized by the legislator in respect of the parties and the injured parties who have remained passive in cases in which a participant in the trial other than the appellant has formulated claims and exceptions or the pre-trial Chamber judged has raised, ex officio, exceptions. The exclusion of the appeal against the judgment by which the pre-trial Chamber judge ordered the commencement of the trial - provided that he found that no claims and exceptions had been made or exceptions raised ex officio - creates discriminatory treatment for the accused, the injured party, the civil party and the civilly liable party in that case in relation to the parties and injured parties who in turn remained liable in those criminal cases in which the pre-trial Chamber judge raised, ex officio, exceptions or claims and exceptions were formulated by a party other than the appellant - party, injured party or prosecutor. Although they are in similar situations, the parties and injured parties from the two mentioned categories benefit from a different legal treatment in terms of the possibility to file an appeal under Article 347 para. 1 of the Criminal Procedure Code, depending on the procedural attitude of another participant in the criminal trial - party, injured party or judicial body - which is in contradiction with the provisions of Article 16 of the Romanian Constitution, given that the discriminatory treatment does not have any objective and reasonable justification. However, from the perspective of the interest to request and obtain the correction of legal errors committed in verifying, after sending to court, the legality of the referral brought before the court of law, as well as in verifying the legality of the adduction of evidence and procedural acts undertaken by prosecution, parties and injured parties to the cases where no claims and exceptions have been made and no exceptions have been raised ex officio are in a similar situation, in terms of recognizing the free access to justice, with the parties and the injured parties who remain in their turn in criminal cases in which the pre-trial Chamber judge raised, ex officio, exceptions or a participant in the trial other than the appellant formulated claims and exceptions. The Court has found that the differentiated legal treatment resulting from the impugned legal provisions is unjustified and leads to discrimination.

Furthermore, regarding the role of the prosecutor in criminal proceedings, the Court noted that, according to the provisions of Article 131 of the Romanian Constitution, in judicial activity, the Public Ministry represents the general interests of society and defends the rule of law and the citizens' rights and freedoms, exercising their attributions through prosecutors established in prosecutor's offices. Therefore, starting from the purpose of the appeal - to ensure the possibility of correcting the errors of law committed during the settlement of the case in the pre-trial Chamber stage - and from the role of the prosecutor, who, as the Romanian Constitutional Court held in its case-law, acts as a lawyer of the general interests of the society, but also of the parties to the lawsuit, in the spirit of legality ${ }^{18}$, the Court held that the requirements

${ }^{18}$ Romanian Constitutional Court's Decision no. 983 of July $8^{\text {th }}, 2010$, published in the Official Gazette of Romania no. 551 of August $5^{\text {th }}, 2010$, and Decision no. 641 of November $11^{\text {th }}, 2014$, cited above, para. 51.

CONSTITUTIONAL NEWS 
of Article 131 of the Romanian Constitution require the legislator to ensure that, through the appeal provided by the provisions of Article 347 para. 1 of the Criminal Procedure Code, in the wording in force prior to the amendment by Law no. $75 / 2016$, to verify, including at the initiative of the prosecutor, the legality of the judgements issued by the pre-trial Chamber judge based on Article 346 para. 2 of the Criminal Procedure Code, in the wording prior to the amendment by Law no. $75 / 2016$. The Court held that if the law - the rule of criminal procedure and/or the rule of substantive criminal law is violated, both the prosecutor and the accused, the injured party, the civil party and the civilly liable party must be given the opportunity to request demands and obtain the restoration of legality by a new wording of the unlawful solution. On the one hand, the impugned provisions of the law deprive the parties and the injured party of the possibility of defending their rights, freedoms and legitimate interests, and, on the other hand, deprive the prosecutor of the tools necessary to exercise his specific role in criminal proceedings. Considering that the outcome of the pre-trial Chamber procedure regarding the establishment of the legality of the adduction of evidence and the procedural acts undertaken by prosecution has a direct influence on the conduct of proceedings on the substance, and could be decisive for establishing the guilt or innocence of the accused ${ }^{19}$, the Court found that the guarantees contained in the provisions of Article 21 and Article 131 of the Basic Law - as these texts have been interpreted in the case-law of the Constitutional Court - require that the prosecutor, the parties and the injured party be given the opportunity to appeal against the judgment by which the pre-trial Chamber judge orders the commencement of the lawsuit if no claims and exceptions have been made nor exceptions raised ex officio. Therefore, the legislative solution contained in the provisions of Article 347 para. 1 of the Criminal Procedure Code, in the wording in force prior to the amendment by Law no. 75/2016, which excludes the appeal against the judgment pronounced by the pre-trial Chamber judge pursuant to Article 346 para. 2 of the Criminal Procedure Code, violates the constitutional provisions of Article 16 of the Romanian Constitution, regarding equality in rights, of Article 21 of the Romanian Constitutions, regarding the free access to justice and of Article 131 of the Romanian Constitution, regarding the role of the Public Ministry.

For similar reasons, invoking Romanian Constitutional Court's Decision no. 18 of January $17^{\text {th }}, 2017$, the Court found, by Romanian Constitutional Court's Decision no. 243 of 16 April $2019^{20}$, that the legislative solution contained in Article 341 para. 9 of the Criminal Procedure Code, which excludes the possibility to appeal against the judgment of the pre-trial Chamber judge regarding the order to commence the lawsuit regarding the facts and parties for whom, during criminal investigation, the criminal action was initiated, pronounced pursuant to Article 341 para. 7 pnt. 2 letter c) of the

${ }^{19}$ Decision no. 631 of October $8^{\text {th }}, 2015$, published in the Official Gazette of Romania no. 831 of November $6^{\text {th }}, 2015$, para. 34 .

${ }^{20}$ Published in the Official Gazette of Romania no. 429 of May 30 2019. 
Criminal Procedure Code, is unconstitutional, being contrary to the constitutional provisions of Article 16 regarding equality in rights, of Article 21 regarding the free access to justice, of Article 24 regarding the right to defence and of Article 131 regarding the role of the Public Ministry.

\section{It is unconstitutional the lack of an appeal against the judgment by which} the pre-trial Chamber judge of a court of law higher than the one notified with the indictment adjudicates, in the first instance, on some preventive measures ordered in the case.

In this regard, the Romanian Constitutional Court ruled by Decision no. 437 of June $\mathbf{2 2 ^ { \text { nd } }}, \mathbf{2 0 1 7 ^ { 2 1 }}$, ruling on the criticism of Article 348 of the Criminal Procedure Code Preventive measures in the pre-trial Chamber procedure, that, prior to the entry into force of Law no. 75/2016, all procedural incidents regarding preventive measures occurred between the date of pronouncing the judgment by the pre-trial Chamber judge from the court of law notified with the indictment, against which an appeal was filed, according to the provisions of Article 347 of the Criminal Procedure Code, and the date of settlement of the respective appeal by the pre-trial Chamber judge from the hierarchically superior court of law, were settled by the pre-trial Chamber judge who pronounced the contested judgment. Following the amendment of Article 348 para. 2 of the Criminal Procedure Code, by pnt. 15 of the sole article of Law no. 75/2016, the competence to rule on preventive measures, within the term indicated above, rests with the pre-trial Chamber judge of the hierarchically superior court of law or the competent panel of the High Court of Cassation and Justice, if the court of law notified with the indictment is the High Court of Cassation and Justice, invested with the settlement of the appeal. Under these circumstances, according to the impugned text, if the pre-trial Chamber judge from the court of law notified with the indictment, upon request or ex officio, decides on taking, maintaining or replacing preventive measures, according to Article 348 para. 1 of the Criminal Procedure Code, and the judgement pronounced is contested, according to Article 347 of the same Code, also the preventive measures ordered or extended expire prior to the settlement of the appeal by the pre-trial Chamber judge of the superior court of law, the competence to rule on the respective preventive measures rests with the pre-trial Chamber judge of the hierarchically superior court of law. This legal solution is an exception to the provisions of Article 347 para. 4 of the Criminal Procedure Code, legal provisions introduced in Article 347 previously referred to, also through the sole article of Law no. 75/2016. According to this provisions, in the settlement of the appeal against the judgment of the pre-trial Chamber judge no other claims or exceptions can be invoked or raised ex officio than those invoked or raised ex officio before the pre-trial Chamber judge in the

${ }^{21}$ Published in the Official Gazette of Romania no. 763 of September $26^{\text {th }}, 2017$.

CONSTITUTIONAL NEWS 
procedure conducted before the court of law notified with the indictment, except in cases of absolute nullity. Because against the judgement by which the appeal is settled, formulated pursuant to Article 347 of the Criminal Procedure Code, the Criminal Procedure Code does not provide for the possibility of promoting an appeal, the pre-trial Chamber judge of the superior court of law decides, in the analysed legal hypothesis, in the first and last instance on preventive measures.

Under these circumstances, in the analysed legal hypothesis, against the judgement by which the preventive measures are ordered by the pre-trial Chamber judge from the superior court of law, the appeal of the referral contained in Article 205 of the Criminal Procedure Code cannot be promoted. Therefore, per a contrario and as the courts of law that have notified, ex officio, the Constitutional Court with the respective exception of unconstitutionality, in the legal hypothesis considered, the accused and the prosecutor cannot formulate an appeal against the judgement by which the pre-trial Chamber judge from the hierarchically superior court of law to the one notified with the indictment is pronounced, in the first instance, regarding the preventive measures.

The Court also found that the holders of the right to formulate the appeal regulated in Article 205 of the Criminal Procedure Code are the accused and the prosecutor. However, having regard to the similarity of the situation of the ruling on preventive measures by the pre-trial Chamber judge from court of law notified with the indictment with that of the ruling on such measures by the pre-trial Chamber judge of the hierarchically superior court of law, in terms of interest on challenging the preventive measures ordered in the first instance, the Court considered that the impugned text violates the constitutional provisions of Article 129, in conjunction with those of Article 131 of the Romanian Constitution, and regarding the right of the Public Ministry to exercise the right of appeal if the pre-trial Chamber judge of the court hierarchically superior to the one notified with the indictment decides, in the first instance, on the preventive measures ordered in the case. Basically, in the legal hypothesis invoked in support of the exception, the prosecutor is deprived of the tools necessary to exercise his specific role in the criminal proceedings. Considering that the provisions of Article 348 para. 2 of the Criminal Procedure Code provide the same legal solution and with reference to the competent panel of the High Court of Cassation and Justice, invested with the settlement of the appeal, the above considerations are valid, accordingly, in its regard. As a result, the Romanian Constitutional Court allowed the exception of unconstitutionality of the provisions of Article 348 para. 2 of the Criminal Procedure Code and found that the phrase "or, as the case may be, the pre-trial Chamber judge of the hierarchically superior court of law or the competent panel of the High Court of Cassation and Justice, invested with the settlement of the appeal' is unconstitutional. 
7. It is unconstitutional the lack of a separate appeal against the precautionary measure taken by the pre-trial Chamber judge or by the court of law, whether it is the court of first instance or the court of appeal.

We shall mention, in this context, even if it does not refer strictly to the provisions of Articles 342-348 of the Criminal Procedure Code, the Romanian Constitutional Court's Decision no. 24 of January $20^{\text {th }}, 2016^{22}$, by which, settling an exception of unconstitutionality raised directly by the Ombudsman, having as object the provisions of Article 250 para. 6 of the Criminal Procedure Code, with the marginal name "Contestation of precautionary measures", the Court held that the immediately exclusion from judicial review of the judgement by which the pre-trial Chamber judge or the court of law rules on precautionary measures in criminal proceedings results in a violation of the free access to justice, since, on the one hand, the parties concerned are deprived of an effective procedural guarantee for the defence of their property right to justice harmed by the establishment of these measures, and, on the other hand, the substance of the right established by the provisions of Article 21 para. 1 of the Basic Law is infringed in the event that the precautionary measure was ordered on appeal. The constitutional principle of free access to justice for the protection of legitimate rights and interests, but also that of legality that must govern the criminal proceedings, exclude the possibility that the right of any interested party could be limited only to challenging the enforcement of the precautionary measure ordered by the pre-trial Chamber judge or by the court of law, because during the criminal proceedings there may be situations in which the circumstance considered at the time of ordering this measure does not comply with the legal requirements, and there is no objective or rational justification to deny the right of the party concerned to notify the court for the defence of his rights.

The Court also noted that according to the provisions of Article 129 of the Romanian Constitution, "against decisions of the court, the parties concerned and the Public Ministry may exercise ways of appeal, in accordance with the law". This constitutional rule includes two theses, namely, the first thesis enshrines the subjective right of any party to a lawsuit, regardless of the subject matter of the lawsuit, as well as the right of the Public Ministry to exercise ways of appeal against judgements considered unlawful or unfounded, the second thesis provides that the exercise of ways of appeal may be carried out under the law. The first thesis expresses in fact, in other words, the fundamental right enshrined in Article 21 of the Romanian Constitution, regarding the free access to justice, which therefore contains a substantial regulation. However, the second thesis refers to procedural rules, which cannot infringe the substance of the right conferred by the first thesis. Therefore, regarding the conditions for exercising ways of appeal, the legislator may regulate the terms for their declaration,

${ }^{22}$ Published in the Official Gazette of Romania no. 276 of April 12th 2016.

CONSTITUTIONAL NEWS 
the wording in which the declaration must be made, its content, the court of law to which it shall be submitted, the competence and the way of judging, the solutions that can be adopted and others of the same kind, as provided by Article 126 para. 2 of the Romanian Constitution, republished, according to which "the jurisdiction of the courts of law and the judging procedure shall only be stipulated by law". However, although Article 129 of the Romanian Constitution ensures the use of ways of appeal "under the law", this constitutional provision does not mean that the "law" could remove or restrict the exercise of other rights or freedoms expressly enshrined in the Constitution.

Therefore, as the right to a fair trial can be viewed in connection with the violation or denial of procedural guarantees regarding civil rights, namely the right to private property, the Romanian Constitutional Court held that the regulation of an effective way of appeal for the benefit of parties whose property is harmed by restrictive procedural measures consists of a constitutional requirement that the legislator must comply with in order to protect and guarantee the right to private property. Therefore, the legislator, in addition to the obligation to give any party the effective opportunity to notify the court in order to defend his rights, freedoms and legitimate interests, must give this possibility a fair character that would give fullness of exercise by achieving the intended purpose. This can be achieved by creating a procedure that complies with the equity requirements provided for by Article 21 para. 3 of the Romanian Constitution, in the absence of which any censorship of the precautionary measure by the court of law shall be emptied of its content. The requirement is all the more obvious as the decision of the court of first instance, settling the conflict of criminal law, falls into the category of acts by which justice is done and whose verification is undertaken by the court of appeal, from the perspective of ensuring a standard as close as possible to that of a normal protection of the right to a fair trial, in a far too long period of time. The simple right of the party concerned notifying the court of law in this way becomes formal as long as the guarantees specific to the fair trial are not complied with. The fairness of the procedure enshrined in Article 21 para. 3 of the Romanian Constitution consists of an explicit capitalization of the provisions of Article 6 of the ECHR. Thus, the aspects related to the observance of the right to a fair trial shall be examined according to the whole lawsuit and to the own principles of organization of each procedure. In this regard, the Court found that the effectiveness of the fair trial guarantees must be applied not only in the pre-trial stages ${ }^{23}$, but also in the subsequent stages (pre-trial Chamber, merits or appeal).

Consequently, the fact that the judgement of the pre-trial Chamber judge or the court of law ordering the precautionary measure can be appealed only once with the sentence does not confer a sufficient argument to cover the shortcomings revealed,

${ }^{23}$ See in this regard the provisions of Article 250 para. 1 of the Criminal Procedure Code according to which the suspect, the accused or any another interested party benefits from the way of appeal not only against the manner of carrying out the precautionary measure undertaken by the prosecutor, but also against the measure itself. 
shortcomings that are undeniably convertible in violation of the right to a fair trial. Moreover, if the decision for taking precautionary measures has been ordered by the court of appeal, then any possibility of the party concerned to exercise his substantive right of the access to justice is denied. In the absence of ensuring an effective judicial review over the measure of making the goods unavailable during a criminal lawsuit, the State does not fulfil its constitutional obligation to guarantee the private property of the natural or legal person. The obligation of guarantee refers both to the duty of the State to refrain from any impairment of the private property right and to the regulation from a normative point of view of some positive measures able to ensure the quiet possession, use and order over the goods. However, the creation of a normative framework that weakens the guarantees that the State must establish regarding the attributes of the private property right leads to the disregard of its obligation undertaken by the text of the Constitution and implicitly to the violation of the private property right. Likewise, the Court noted that the vulnerability of the person's private property has the effect of creating a regime of legal insecurity, his property right becoming illusory.

It is important to emphasize that in the recitals of the decision, the Romanian Constitutional Court expressly held that "pending the adoption of the appropriate legislative solution, as a consequence of this decision of allowing the exception of unconstitutionality, the Court finds that the courts of law are to apply directly Article 21 para. 1 and 3 and Article 129 of the Constitution".

8. The legis/ative solution contained in the provisions of Article 282 para. 2 of the Criminal Procedure Code is unconstitutional, which does not allow the ex officio invocation of relative nullity.

Likewise, even if it does not refer strictly to the provisions of Articles 342-348 of the Criminal Procedure Code, we also mention the Romanian Constitutional Court's Decision no. 554 of September $\mathbf{1 9}$ th, $\mathbf{2 0 1 7 ^ { 2 4 }}$, whereby the Court allowed the exception of unconstitutionality and found that the legislative solution contained in the provisions of Article 282 para. 2 of the Criminal Procedure Code, which does not allow the ex officio invocation of relative nullity, is unconstitutional. In this case, the exception was raised by the pre-trial Chamber judge, who argued, in essence, that the provisions of the impugned law violate the constitutional provisions of Article 1 para. 5 on the principle of legality and Article 21 para. 3 concerning the right to a fair trial, as it prevents the pre-trial Chamber judge from taking into account ex officio the relative nullities regarding the act of referral to the court, the adduction of evidence and the criminal proceedings undertaken.

${ }^{24}$ Published in the Official Gazette of Romania no. 1013 of December 21st, 2017.

CONSTITUTIONAL NEWS 
Firstly referring to the regulation of nullities in criminal proceedings, the Romanian Constitutional Court found that the provisions of Article 282 para. 2 of the Criminal Procedure Code establish the rule according to which the judge or the court of law cannot take into account, ex officio, the violations of the rules governing the conduct of the criminal proceedings, even if these violations would be likely to impair the finding of the truth and the just settlement of the case. As a result, the legislative solution contained in the provisions of Article 282 para. 2 of the Criminal Procedure Code, which does not allow the ex officio invocation of relative nullity, infringes the constitutional provisions of Article 1 para. 3 and 5 of the Romanian Constitution, regarding the rule of law - in its component regarding the justice as the supreme value - and the principle of legality and of Article 124 of the Romanian Constitution regarding the enforcement of justice, for the reasons shown below.

The Court noted that the rules governing the adduction of evidence are of the utmost importance in the conduct of the material part of the criminal proceedings, namely that which leads directly to the application of criminal law. By their nature, certain means of evidence are impossible to regather or, even if this possibility exists, the judicial body may reject that as it is not useful to regather a means of evidence already submitted in the file. The legal procedures for obtaining evidences are primarily intended to ensure their accuracy and non-corruption, so as to ensure that the objective reality of the facts is reflected in that evidences. The current Criminal Procedure Code introduces the concept of excluding unlawfully obtained evidence. By Romanian Constitutional Court's Decision no. 840 of December $8^{\text {th }}, 2015$, cited above, the Court found that evidence cannot be unlawfully obtained unless the means of evidence and/or the trial evidence by which it is obtained is unlawful, which presupposes the unlawfulness of ordering, authorizing or gathering the evidence. However, their unlawfulness is sanctioned by the provisions of Article 102 para. 3 of the Criminal Procedure Code, by applying the regime of absolute or relative nullity. This is because the nullities, as they are regulated by Articles 280-282 of the Criminal Procedure Code, concern only the proceedings and procedural acts, namely the means of evidence and the trial evidence, and not the evidence itself, which are only factual elements. Therefore, it is natural to apply the nullity regime, according to Article 102 para. 3 of the Criminal Procedure Code, only to the acts by which the evidence was ordered or authorized and to the acts by which it was adduced (para. 16). Consequently, the Court considered that Article 102 para. 2 and 3 of the Criminal Procedure Code must be in conjunction, which means that the evidences obtained by the documents provided for in Article 102 para. 3 of the Criminal Procedure Code may not be used in criminal proceedings provided that these acts are impaired by absolute or relative nullity. The two paragraphs do not regulate different institutions, but always imply the application of the regime of nullities in the matter of trial evidence, as it is regulated by Articles 280-282 of the Criminal Procedure Code, and the result of the nullity of documents, respectively of means of evidence determines the impossibility of using evidence in the 
lawsuit (para. 17). Likewise, the Court noted that, from the content of the general rules on the trial evidence, three categories of actions can be inferred which may vitiate the evidence, namely: a breach of the procedural requirements for their adduction; obtaining evidence by using unlawful methods; establishing the content of the evidence which is not in compliance with the objective reality that it must reflect.

Therefore, the exclusion of evidence is not an independent sanction, but is an effect of the finding of the nullity of the evidence or the trial evidence by which it is transposed in the file. This effect of nullity in the matter of trial evidence was understood in the conception of the Criminal Procedure Code of 1968, while in the new Code it is explicitly regulated, the provisions governing nullities being of general application, without excluding from them the proceedings and the procedural acts undertaken in the trial evidence. Consequently, in order to rule out the exclusion of evidence, it must be held that it was unlawfully obtained. In order to establish that the evidence was unlawfully obtained, it must be established that the means of evidence or the trial evidence by which the evidence was objected were invalid in principle. In order to establish the relative nullity of the means of evidence or the trial evidence, this nullity must be invoked by the interested party, within a certain procedural period of time. The non-invocation or late invocation of the nullity entails the maintenance as legal of the means of evidence or the trial evidence and this makes it impossible to exclude the evidence, because a means of legal evidence or the trial evidence that challenges an unlawfully obtained evidence would be a contradiction in terms. Thus, although, in reality, it is flawed, the evidence maintained can contribute to the erroneous establishment of the factual situation. In view of those mentioned above, the Romanian Constitutional Court found that the legislative solution contained in the provisions of Article 282 para. 2 of the Criminal Procedure Code, which does not allow the relative invocation of relative nullity, violates the provisions of Article 1 para. 3 and 5 and of Article 124 of the Romanian Constitution, preventing the judge or the court of law from considering ex officio the violation of legal provisions whose non-compliance is likely to lead to the relative nullity of the act, except for the situations expressly provided for by law.

Considering the importance of the procedural stage of the pre-trial Chamber and the role that the pre-trial Chamber judge occupies in the criminal proceedings, given that the outcome of the pre-trial Chamber procedure regarding the establishment of the legality of the adduction of evidence and the procedural acts undertaken by prosecution has a direct influence on the conduct of proceedings on the substance, and could be decisive for establishing the guilt or innocence of the defendant ${ }^{25}$, the Court held that there was no objective and reasonable justification for preventing the pre-trial Chamber judge from considering ex officio the infringements which entail relative

\footnotetext{
${ }^{25}$ Romanian Constitutional Court's Decision no. 631 of October $8^{\text {th }}, 2015$, published in the Official Gazette of Romania no. 831 of November $6^{\text {th }}, 2015$, para. 34 .
}

CONSTITUTIONAL NEWS 
nullity. Likewise, regarding the role of the court of law in the criminal proceedings stage, the Court considered that such a legislative solution - which does not allow, as a rule, the ex officio invocation of relative nullity - cannot be justified only by the philosophy of restricting the active role of the court of law and, in general, by rethinking the system of criminal proceedings, in the sense of bringing it closer, in certain respects, to the adversarial system. In this regard, the Court noted that, unlike the adversarial system, in which the judge bears responsibility, in principle, only on the correctness of the proceedings, the task of establishing the facts and guilt of the jurors, in the Romanian criminal proceedings the court of law takes responsibility for these essential elements, which constitute the purpose of the lawsuit. Thus, the Court noted that, on the one hand, the new Criminal Procedure Code requires the court of law to neglect certain irregularities, although they could also lead to the vitiation of the outcome of the proceedings, but, on the other hand, the same court of law is responsible for the solution pronounced. However, the reasons for which it was previously legislated the possibility for the court of law to take into account the relative nullity ex officio - in compliance with certain conditions provided by law - are still maintained today, because they are based on factual situations, they cannot have another solution, factual situations that continue to appear even after the entry into force of the new Criminal Procedure Code.

\section{Unconstitutionality of the regulation of a term within which absolute} nullity can be invoked in case of non-assistance by a lawyer.

Thus, we shall mention the Romanian Constitutional Court's Decision no. 88 of February $13^{\text {th }}, \mathbf{2 0 1 9 ^ { 2 6 }}$, by which the Court found that by legislating a term within which absolute nullity can be invoked in case of non-assistance by a lawyer, although the law provides for this obligation, a contradictory situation is reached. Thus, the legislator establishes a term that limits the possibility of invoking absolute nullity, although it absolutely presumes that the party present at the debates requires the assistance of a lawyer in order to make an effective defence, which also involves invoking nullity. However, even in the case-law of the courts of law, it has been held that the right to an effective defence occupies a central place in the conduct of criminal proceedings, its importance being that all other rights would remain derisory, without procedural guarantees, and the judicial authorities shall have the obligation to ensure this right. To ensure a real defence is a guarantee, a sure premise of the objective and complete investigation of the evidence, a sine qua non condition of finding the truth, of defending the rights and legal interests of the accused, creating necessary conditions for issuing a legal and solid sentence.

${ }^{26}$ Published in the Official Gazette of Romania no. 499 of June 20 2019.

CONSTITUTIONAL LAW REVIEW 


\section{Constitutionalisation of the Pre-trial Chamber concept}

Thus, by establishing a term within which the exception of absolute nullity can be raised in case of non-assistance by a lawyer in the pre-trial Chamber procedure, although the law provided for this obligation, the legislator empties the fundamental right to defence of its content, ensured by assistance by a lawyer appointed ex officio, in the cases expressly provided for by law. Thus, although the breach of the obligation by the judicial body is sanctioned by the legislator with absolute nullity, the applicable sanction appears to be ineffective under the conditions of establishing a term (judgment of the pre-trial Chamber procedure) until which absolute nullity resulting from non-compliance in the pre-trial Chamber stage with the provision regarding the obligation to be assisted by a lawyer can be invoked.

Further, the Romanian Constitutional Court observed that among the cases of absolute nullity that can be invoked in any stage of the lawsuit is the one regulated by the provisions of Article 281 para. 1 letter d) of the Criminal Procedure Code regarding the non-participation of the prosecutor, when his participation shall be mandatory according to the law. The provisions of Article 90 of the Criminal Procedure Code regulate the cases of compulsory legal assistance, applicable also during the pre-trial Chamber procedure. On the other hand, according to Article 344 para. 4 of the Criminal Procedure Code, "at the expiration of the terms provided in para. 2 and 3, if claims or exceptions have been made or exceptions has been raised ex officio, the pre-trial Chamber judge establishes the term for their settlement, with the summoning of the parties and the injured party and with the participation of the prosecutor". It follows from the above provisions that disregard of both legal provisions may occur in the pre-trial Chamber procedure and the violation shall be sanctioned in both cases with absolute nullity. However, the legislator regulated differently the time until which absolute nullity can be invoked, depending on the procedural provisions violated. Thus, if such provisions were not complied with during the same criminal proceedings, it is reached the situation in which, considering the distinction made by the legislator regarding the term of invocation of absolute nullity, the absolute nullity deriving from the lack of assistance of the accused or of the other parties, when this is mandatory according to the law, may be invoked until the judgment of the pre-trial Chamber procedure is finished [according to Article 281 para. 4 letter a) of the Criminal Procedure Code], while the absolute nullity deriving from the non-participation of the prosecutor, when his participation is mandatory according to the law, may be invoked both in the pre-trial Chamber and during the criminal proceedings (according to Article 281 para. 3 of the Criminal Procedure Code).

The reason for such a provision concerning the setting of a time limit within which absolute nullity may be invoked may be generated by the role of the procedural stage of the pre-trial Chamber, which must examine precisely the irregularities of procedure before the trial stage, in order for the latter to obtain the celerity imposed by the requirement to settle the case within a reasonable time. Thus, the regulation of a new structure of the criminal proceedings in conjunction with the need to settle the case

CONSTITUTIONAL NEWS 
(trial stage) within a reasonable time would be a reason underlying the legislator's option to rule in certain cases a time limit until which absolute nullity can be raised. In this context, the Romanian Constitutional Court found that the settlement of the case within a reasonable time is limited to a legitimate aim, and the regulation of a new structure of the criminal proceedings may determine and justify certain legislative options. However, the Romanian Constitutional Court notes that in its case-law ${ }^{27}$ found that the outcome of the pre-trial Chamber procedure regarding the establishment of the legality of the adduction of evidence and the procedural acts undertaken by prosecution has a direct influence on the conduct of the proceedings on the substance, and may be decisive for establishing the guilt or innocence of the accused. However, given the importance of this stage and the fact that, in cases where the law regulates mandatory assistance, the right to a defence can be exercised effectively only by the presence of a lawyer, the Court has found that the regulation of a new stage of criminal proceedings is not a well-founded reason justifying the enactment of a time limit, namely the judgment of the pre-trial Chamber procedure, until which the violation of the legal provisions regarding the obligatory assistance of the accused in the pre-trial Chamber procedure can be invoked.

\section{Conclusions}

The decisions of the Romanian Constitutional Court are generally binding, which determines the obligation of the legislator to intervene, under the conditions of Article 147 para. 1 of the Constitution, in order to comply the provisions found as unconstitutional with the provisions of the Constitution. In the matter of criminal procedure, as well as of substantial criminal law, it has been found, in recent years, the lack of legislative intervention in the sense shown, or, rather, attempts by the legislature to amend the criminal law, failed precisely because in the content they have new elements of unconstitutionality ${ }^{28}$.

${ }^{27}$ For example, Decision no. 631 of October $8^{\text {th }}, 2015$, published in the Official Gazette of Romania no. 831 of November $6^{\text {th }}, 2015$, Decision no. 641 of November $11^{\text {th }}, 2014$, published in the Official Gazette of Romania no. 887 of December $5^{\text {th }}, 2014$ and Decision no. 257 of April 26 th, 2017 , published in the Official Gazette of Romania no. 472 of June $22^{\text {nd }}, 2017$.

${ }^{28}$ See Romanian Constitutional Court's Decision no.650 of October $25^{\text {th }}, 2018$, regarding the objection of unconstitutionality of the provisions of Article I pnt. 2 (with reference to Article 5 para. $1^{1}-1^{4}$ ), pnt. 4 [with reference to Article 17 letter a)], pnt. 5 (with reference to Article 35 para. 1 second thesis), pnt. 6 [with reference to Article 39 para. 1 letter b), c) and e)], pnt. 10 (with reference to Article 64 para. 1), pnt. 11 (with reference to the repeal of Article 64 para. 6), pnt. 13 [with reference to Article 75 para. 1 letter d)], pnt. 14 (with reference to Article 75 para. 2 letter d)], pnt. 15 (with reference to Article 75 para. 3), pnt. 17 [with reference to the repeal of Article 91 para. 1 letter c)], pnt. 20 (with reference to Article 96 para. 4), pnt. 21 (with reference to Article 100), pnt. 22 (with reference to Article $112^{1}$ para. 1 and 2), pnt. 23 (with reference to Article $112^{1}$ para. $2^{1}$ ), pnt. 24 (with reference to Article $112^{1}$ para. (3), pnt. 26 [with reference to Article 154 para. (1) letters b) and c)], pnt. 27 (with reference to Article 155 para. 2 and 3), Article I pnt. 28 (with reference to Article 1591), pnt. 29 (with reference to Article 173 para. 2-5), pnt. 30 (with reference to the repeal of Article 175 para. 2),

CONSTITUTIONAL LAW REVIEW 
However, we emphasize that, given the express provisions of Article 147 para. 1 of the Romanian Constitution, the passivity of the legislator cannot be an obstacle to the effectiveness of constitutional justice. Even in the absence of his intervention, after the period of 45 days from the publication of the decision of the Constitutional Court in the Official Gazette, the provisions found to be unconstitutional cease to be applicable, and this effect is erga omnes, under Article 147 para. 4 of the Constitution.

Anyway, as the Court has held ${ }^{29}$, even if, in principle, in the procedure of complying a law or rule found unconstitutional with a decision of the Constitutional Court, the Parliament shall be free to decide whether to amend that law or rule strictly within the meaning of those ruled by the Court or to abandon the intervention on the text in question by eliminating the rule or even by rejecting the law, this freedom is restricted when a decision of the Constitutional Court is pronounced within the $a$ posteriori review by which the rule in force, which is the object of the legislative intervention, was declared unconstitutional. Therefore, in the case of the interference of the effects of the pronounced decisions on the exceptions of unconstitutionality of the laws and ordinances in force, "once the procedure for amending the law has been initiated in order to bring it into line with the Constitution, Parliament is obliged to adopt the rules transposing the jurisdictional act of the Court, eliminating the flaws of unconstitutionality found". As a result, the obligation to bring the provisions of the Criminal Procedure Code into line with the Constitution subsists, becoming, we would say, more pressing, as decisions of unconstitutionality accumulate. But as we stated before $^{30}$, in order to ensure the effectiveness of criminal justice and the fulfilment of commitments undertaken as a Member State of the European Union, legislative proposals by which criminal law is brought into line with decisions of the Constitutional Court or transposing European Union acts shall be treated separately from other

pnt. 31 [with reference to Article 177 para. 1 letters b) and c)], pnt. 32 (with reference to Article 187¹), pnt. 33 [with reference to Article 189 para. 1 letter i)], pnt. 38 (with reference to Article 257 para. (4), pnt. 39 (with reference to Article 269 para. 3), pnt. 40 (with reference to Article 269 para. 4-6), pnt. 41 (with reference to Article 273 para. 4), pnt. 42 (with reference to Article 277 para. 1-3), pnt. 43 (with reference to Article 277 para. $3^{1}$ and $3^{2}$ ), pnt. 46 (with reference to Article 290 para. 3), pnt. 47 (with reference to Article 291 para. 1), pnt. 49 (with reference to Article 295 para. 3), pnt. 50 (with reference to Article 297 para. 1), pnt. 51 (with reference to Article 297 para. 3), pnt. 52 (with reference to the repeal of Article 298), pnt. 53 (with reference to Article 308 para. 3 and 4), pnt. 54 (with reference to Article 309) and pnt. 62 (with reference to Article 367 para. 6), Article II (with reference to the phrase "verified evidence") and Article III of Law amending and supplementing Law no. 286/2009 on the Criminal Code, as well as Law no. 78/2000 for the prevention, detection and sanctioning of acts of corruption, as well as of the law as a whole, published in the Official Gazette of Romania no. 97 of February 7th 2019 ; Decision no. 467 of July 29th, 2019 on the objection of unconstitutionality of the provisions of Law for amending and supplementing Law no. 135/2010 regarding the Criminal Procedure Code, as well as for amending and supplementing Law no. 304/2004 on judicial organization, published in the Official Gazette of Romania no. 765 of September 20 2019.

${ }^{29}$ The Romanian Constitutional Court's Decision no. 467 of July 29th, 2019, cited above; see M. Safta, Parliament's re-examination of the law. Characterization and jurisprudential developments, Legislative Information Bulletin published by the Legislative Council no. 4/2019.

${ }^{30}$ T. Toader, M. Safta, Who does the criminal policy in Romania?, in Constitutional Law Review no. 1/2019.

CONSTITUTIONAL NEWS 


\section{Tudorel TOADER • Marieta SAFTA}

planned amendments with regard to criminal law and with due celerity ${ }^{31}$, in order to avoid serious consequences upon legal certainty.

With regard to the matter analysed here, taking into account the fact that by the pronounced decisions, the Court substantially reconfigured the procedural stage of the pre-trial Chamber, and the adoption by the legislature of certain rules contrary to those decided in a decision of the Constitutional Court, keeping the legislative solutions impaired by constitutional flaws, violates the Basic Law ${ }^{32}$, a question arises whether the current regulation of this stage is still in compliance with the intention to regulate, respectively the role considered by the legislator in the whole criminal proceedings. In this light, we consider that a legislative intervention on the concept as a whole is necessary, in order to avoid the risk of "doubling the trial stage" 33 , with consequences diametrically opposed to the original rationale of the regulation.

\footnotetext{
${ }^{31}$ See https://europunkt.ro/2017/06/07/interviu-marieta-safta-secretar-de-stat-la-ministerul-justitiei-con servarea-caracterului-de-exceptie-al-legiferarii-pe-calea-delegarii-legislative-incumba-deopotriva-parlamentului-siguvernului.

32 See Romanian Constitutional Court's Decision no. 895 of December 17th 2015 , published in the Official Gazette of Romania no. 84 of February $4^{\text {th }}$, 2016, para. 26, or Decision no. 581 of July 20th 2016, cited above, para. 49 and 50, Decision no. 432 of June $21^{\text {st }}, 2018$ on the objection of unconstitutionality of the Law amending and supplementing Law no. 334/2006 on financing the activity of political parties and electoral campaigns, published in the Official Gazette of Romania no. 575 of July $6^{\text {th }}, 2018$.

${ }^{33}$ C. Voicu, D. Atasiei, in N. Volonciu (coord.), op. cit., p. 943.
} 